\title{
Pinpointing Brain TREM2 Levels in Two Mouse Models of Alzheimer's Disease
}

\author{
Silvio R. Meier $\odot,{ }^{1}$ Dag Sehlin, ${ }^{1}$ Greta Hultqvist, ${ }^{2}$ Stina Syvänen ${ }^{1}$ \\ ${ }^{1}$ Department of Public Health and Caring Science/Molecular Geriatrics, Rudbecklaboratoriet, Uppsala University, Dag Hammarskjölds \\ Väg 20, Uppsala, Sweden \\ ${ }^{2}$ Department of Pharmaceutical Biosciences/Protein Drug Design, BMC, Uppsala University, Husargatan 3, Uppsala, Sweden
}

\begin{abstract}
Purpose: The triggering receptor expressed on myeloid cells 2 (TREM2) is expressed by brain microglia. Microglial activation, as observed in Alzheimer's disease (AD) as well as in transgenic mice expressing human amyloid-beta, appears to increase soluble TREM2 (sTREM2) levels in CSF and brain. In this study, we used two different transgenic mouse models of AD pathology and investigated the potential of TREM2 to serve as an in vivo biomarker for microglial activation in $\mathrm{AD}$.

Procedures: We designed and generated a bispecific antibody based on the TREM2-specific monoclonal antibody mAb1729, fused to a single-chain variable fragment of the transferrin receptor binding antibody 8D3. The 8D3-moiety enabled transcytosis of the whole bispecific antibody across the blood-brain barrier. The bispecific antibody was radiolabeled with I-125 (ex vivo) or I-124 (PET) and administered to transgenic AD and wild-type (WT) control mice. Radioligand retention in the brain of transgenic animals was compared to WT mice by isolation of brain tissue at $24 \mathrm{~h}$ or $72 \mathrm{~h}$, or with in vivo PET at $24 \mathrm{~h}, 48 \mathrm{~h}$, and $72 \mathrm{~h}$. Intrabrain distribution of radiolabeled $\mathrm{mAb} 1729-\mathrm{scFv} 8 \mathrm{D} 3_{\mathrm{CL}}$ was further studied by autoradiography, while ELISA was used to determine TREM2 brain concentrations.

Results: Transgenic animals displayed higher total exposure, calculated as the AUC based on SUV determined at $24 \mathrm{~h}, 48 \mathrm{~h}$, and $72 \mathrm{~h}$ post injection, of PET radioligand $\left[{ }^{124} \mathrm{l}\right] \mathrm{mAb} 1729-$ scFv8D3 ${ }_{C L}$ than WT mice. However, differences were not evident in single time point PET images or SUVs. Ex vivo autoradiography confirmed higher radioligand concentrations in cortex and thalamus in transgenic mice compared to WT, and TREM2 levels in brain homogenates were considerably higher in transgenic mice compared to WT.

Conclusion: Antibody-based radioligands, engineered to enter the brain, may serve as PET radioligands to follow changes of TREM2 in vivo, but antibody formats with faster systemic clearance to increase the specific signal in relation to that from blood in combination with antibodies showing higher affinity for TREM2 must be developed to further progress this technique for in vivo use.
\end{abstract}

Key words: Alzheimer's disease, PET, TREM2, sTREM2, Bispecific antibody, Neuroinflammation

\section{Introduction}

Alzheimer's disease (AD) is the most common form of dementia. The number of people suffering from $\mathrm{AD}$ is 
expected to increase, mainly due to an older population worldwide as age is the key risk factor for the disease [1]. The complex mechanisms of the disease are not fully understood. Besides the classical disease hallmarks such as extracellular aggregation of the protein amyloid-beta $(A \beta)$ and the formation of intracellular neurofibrillary tau-tangles, glial cells respond strongly to these pathological changes. The resulting inflammatory reaction is believed to be directly linked to the pathogenesis of the disease and may contribute to disease progression and severity [2]. Microglia are resident immune cells of the brain that constantly monitor the environment for signals related to damage [3]. Microglial cells express a wide range of immune receptors. Several missense mutations of the triggering receptor expressed on myeloid cells 2 (TREM2) have previously been reported to increase the risk of developing AD [4]. The receptor undergoes intramembrane proteolysis [5] leading to the release of the extracellular soluble part of TREM2 (sTREM2). sTREM2 can be detected in CSF, and concentrations are already increased in early symptomatic stages of $\mathrm{AD}$ [6]. In addition, sTREM 2 concentrations appear to be correlated with markers for neurodegeneration, e.g., CSF concentrations of total tau and phosphorylated-tau [7, 8]. Brendel et al. (2017) studied sTREM2 levels in brain homogenates obtained from PS2APP mice (transgenic AD model) and reported an age-dependent increase in transgenic mice compared with wild-type (WT) mice [9]. The strong correlation between total $\mathrm{A} \beta$ and sTREM2 reported by Brendel et al. supports the association between amyloidosis and increased sTREM2 [10]. Further, post mortem analysis of sTREM2 concentrations in brain homogenates was compared to positron emission tomography (PET) imaging using the translocator protein (TSPO) radioligand $(4 S)-N, N$ diethyl-9-(2-( $\left.{ }^{18} \mathrm{~F}\right)$ fluoranylethyl)-5-methoxy-1,2,3,4tetrahydrocarbazole-4-carboxamide $\left(\left[{ }^{18} \mathrm{~F}\right] \mathrm{GE} 180\right)$, which images microglial activation, and 4-[(E)-2-(4-\{2-[2-(2$\left[{ }^{18} \mathrm{~F}\right]$ fluoroethoxy)ethoxy] ethoxy phenyl)vinyl]- $N$ methylaniline $\left(\left[{ }^{18} \mathrm{~F}\right]\right.$ florbetaben $)$, which is used to quantify brain $\mathrm{A} \beta$ plaque load [10]. In vivo, TSPO levels correlated well with both sTREM2 and amyloid levels. Interestingly, microglial activation, measured with $\left[{ }^{18} \mathrm{~F}\right] \mathrm{GE} 180$, was reported already at an early age when $A \beta$ deposition was sparse and only detectable by sensitive histological methods but not with $\left[{ }^{18} \mathrm{~F}\right]$ florbetaben PET. This indicates that sTREM2 might serve as a biomarker for microglial activation at a very early disease stage, and thus, it would be beneficial to image and quantify sTREM2 concentrations in vivo with PET imaging. This approach could be an alternative to TSPO PET radioligands that suffer from many challenges such low brain distribution, unspecific and genotype-dependent binding.

Antibodies and antibody fragments have recently been described as PET radioligands for different aggregation forms of $A \beta$ in rodents [11-16]. To cross the blood-brain barrier (BBB), the antibodies, which are too large for passive brain distribution, were fused to a transferrin receptor (TfR) binding moiety based on the $8 \mathrm{D} 3$ antibody $[17,18]$ that enabled active transport across the BBB into cerebral tissue. This strategy increased the brain distribution of the antibodies up to 80 -fold, improved the spatial distribution inside the brain parenchyma, and allowed for their use, after radiolabeling, as in vivo PET radioligands [14, 19, 20]. In the brain, these constructs profit from a very selective and strong binding to the target structure, i.e., $A \beta$ in the previously mentioned studies.

The aim of this study was to investigate TREM2 levels in two transgenic AD mouse models and WT mice and the potential age-dependent changes. Further, we aimed to create a bispecific radioligand that would enable in vivo visualization and quantification of TREM2 with PET. Ex vivo measurement of TREM2 in brain homogenates is likely to correspond to sTREM2 rather than to membrane bound TREM2. However, it should be noted that in vivo, the developed bispecific radioligand could also bind to membrane bound TREM2. Therefore, we have decided to use "TREM2" throughout the manuscript, except when explicitly referring to ELISA measurements in TBS brain extracts.

\section{Materials and Methods}

\section{Bispecific Antibody Preparation}

The bispecific antibody was based on the anti-TREM2 antibody mAb1729 (R\&D, Abingdon, UK) and a modified single-chain variable fragment $(\mathrm{scFv})$ of the TfR binding antibody 8D3 [18] optimized for cross-linking, scFv8D $3_{\mathrm{CL}}$. The $\mathrm{scFv} 8 \mathrm{D} 3_{\mathrm{CL}}$ was generated by adding a lysine-rich sequence at the C-terminus with double FLAG-Tag [21] (2xDYKDDDK) to promote NHS-ester binding at the Cterminus of the scFv8D3. A linker was placed between the $\mathrm{scFv}$ and the lysine-rich part. The linker consisted of amino acid 1-7 of the sequence of mouse Ig lambda-1 $\mathrm{C}_{\mathrm{L}}$ (QPKSSPS) as an endogenous extension of a scFv at its Cterminus. The linker increases the distance and thus flexibility of the added moiety to promote accessibility for subsequent trans-cyclooctene (TCO) functionalization. For nickel purification, a 6xHis tag was added at the very end of the $\mathrm{C}$-terminus. The expression of $\mathrm{scFv} 8 \mathrm{D} 3_{\mathrm{CL}}$ was performed as described by Fang et al. (2018) [22].

In house expressed $\mathrm{scFv} 8 \mathrm{D} 3_{\mathrm{CL}}$ was chemically conjugated to mAb1729 using TCO-tetrazine Diels-Alder "click chemistry" [23] (Fig. 1). Antibody mAb1729 (R\&D), $250 \mu \mathrm{g}(2 \mathrm{mg} / \mathrm{ml})$, was incubated for $2 \mathrm{~h}$ with a 7 -fold excess of axial TCO-NHS (Conju-probe, San Diego, USA) resulting in TCO-conjugation to the antibody. The scFv8D $3_{\mathrm{CL}}(2 \mathrm{mg} / \mathrm{ml})$ was incubated with a 5 -fold excess of tetrazine-PEG5-NHS (Sigma Aldrich, Stockholm, Sweden). Both reactions were stopped by running the reaction solution over desalting columns Zeba $7 \mathrm{kDa}$ (Fisher scientific, Gothenburg, Sweden). Modified proteins were mixed with 10 -fold molar excess of $\mathrm{scFv} 8 \mathrm{D} 3_{\mathrm{CL}}$ and incubated at room temperature for $5 \mathrm{~h}$. Proteins were 


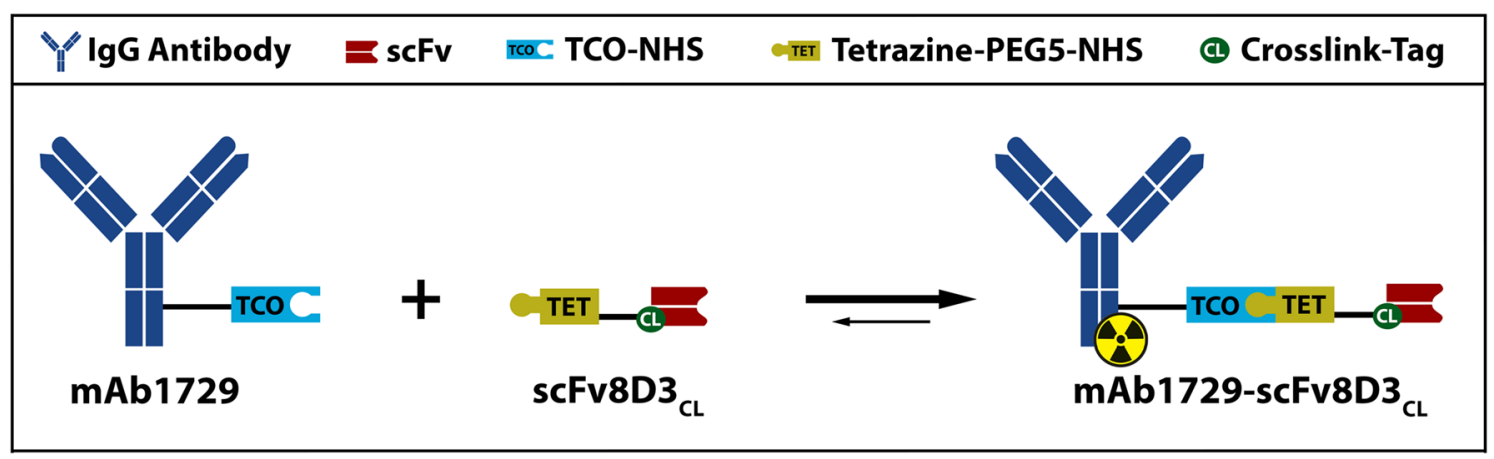

Fig. $1 \mathrm{mAb1729}$ and scFv8D3 $\mathrm{CL}$ were linked to TCO and tetrazine groups, respectively, by NHS-ester conjugation. The functionalized proteins were then conjugated by Diels-Alder reaction to generate the bispecific protein mAb1729-scFv8D3 ${ }_{\mathrm{CL}}$, with the ability to bind both TREM2 and the transferrin receptor. The bispecific protein was radiolabeled with I-125 or I-124 for ex vivo and PET studies, respectively.

separated by gel filtration using an ÄKTA Start system (GE Healthcare, Uppsala, Sweden) with a HiPrep 16/60 Sephacryl S-100 column (Sigma). The final preparation resulted in $79 \%$ single or multiple conjugated mAb1729scFv8D $3_{\mathrm{CL}}, 3 \%$ unconjugated $\mathrm{scFv} 8 \mathrm{D} 3_{\mathrm{CL}}$, and $18 \%$ unconjugated mAb1729.

\section{Radiolabeling and Binding ELISA}

Bispecific antibody mAb1729-scFv8D3 ${ }_{\mathrm{CL}}$ was radiolabeled with I-125 or I-124 (PerkinElmer Inc., Waltham, MA, USA) by direct radioiodination [24]. I-125 labeling: $35 \mu \mathrm{g}$ of protein was diluted in PBS to a concentration of $0.4 \mathrm{mg} / \mathrm{ml}$. $24.5 \pm 5 \mathrm{MBq}$ of $\mathrm{I}-125$ was added followed by $5 \mu 1$ chloramine $\mathrm{T}(1 \mathrm{mg} / \mathrm{ml})$. After 90 -s incubation, the reaction was quenched with $10 \mu \mathrm{l}$ of sodium metabisulfite $(1 \mathrm{mg} / \mathrm{ml})$. The volume was extended to $0.5 \mathrm{ml}$ with $\mathrm{PBS}$ and transferred to a NAP-5 size-exclusion column (GE Healthcare). The labeled protein was eluted with $1 \mathrm{ml}$ PBS collected in 2 fractions $(900 \mu \mathrm{l}, 100 \mu \mathrm{l})$. Only the first fraction was used for injections. I-124 labeling: $65 \mu \mathrm{g}$ of protein was diluted in PBS to a concentration of $0.2 \mathrm{mg} / \mathrm{ml}$. $130 \pm 4 \mathrm{MBq}$ I-124 was added immediately followed by $40 \mu 1$ chloramine $\mathrm{T}(1 \mathrm{mg} / \mathrm{ml})$ and incubated for $120 \mathrm{~s}$. The reaction was quenched by adding $80 \mu 1$ of sodium metabisulfite $(1 \mathrm{mg} / \mathrm{ml})$. The protein was separated from free iodine as described above. Protein labeling yields were $45-50 \%$ for I- 125 and $65-70 \%$ for I- 124 . Binding of labeled and unlabeled mAb1729-scFv8D $3_{\mathrm{CL}}$ was investigated with ELISA to ensure that the affinity to TREM2 and TfR was intact also after radiolabeling. Plates were coated either with TREM2 $(50 \mu \mathrm{g} / \mathrm{well})$ or TfR $(25 \mu \mathrm{g} / \mathrm{well})$ overnight. After $2 \mathrm{~h}$ of blocking with bovine serum albumin (BSA) (Sigma) (1 \%), labeled and unlabeled mAb1729scFv8D $3_{\mathrm{CL}}$ was applied to the ELISA plates in a 5 times dilution series at a starting concentration of $50 \mathrm{nM}$ and incubated for $3 \mathrm{~h}$. Detection was performed with secondary HRP conjugated antibodies (TfR coat: anti myc-tag,
(BioNordika, Solna, Sweden); TREM2 coat: anti-his-tag (Nordic biosite, Täby, Sweden)) and incubated for $2 \mathrm{~h}$. Signal was developed with K-blue Aqueous TMB substrate (LumiraDx, Solna, Sweden) and read with a spectrophotometer at $450 \mathrm{~nm}$.

\section{Animals and In Vivo Experiments}

In vivo experiments were performed in transgenic mouse models harboring the Swedish (Swe) [25] or the Swe and the Arctic mutation (ArcSwe) $[25,26]$ (Sup. Table 1). Prior and during the experiments, animals were housed at controlled temperature $\left(23{ }^{\circ} \mathrm{C}\right)$ and humidity $(50 \%)$ at an animal facility at Uppsala University, with free access to food and water. Brain tissue from one group of previously studied ArcSwe mice that received BACE-1 inhibitor NB360 supplemented food during 3 months, starting at the age of 10 months was also included in the study [27]. The experiments were approved by The Uppsala Country Animal Ethics board (approval 5.8.18-13350/2017).

Ex vivo mice were i.v. administered with $\left[{ }^{125} \mathrm{I}\right] \mathrm{mAb} 1729$ $\mathrm{scFv} 8 \mathrm{D} 3_{\mathrm{CL}}, 0.37 \mathrm{MBq} \pm 0.12 \mathrm{Mbq}(0.3 \mathrm{MBq} / \mu \mathrm{g})$. At the terminal time point, all mice were anaesthetized with $3 \%$ isoflurane and underwent transcardiac perfusion with $40 \mathrm{ml}$ $0.9 \% \mathrm{NaCl}$ during $2.5 \mathrm{~min}$. Main organs were isolated after perfusion, and radioactivity was measured in a Wizard 2470 gamma counter (PerkinElmer). Organ concentrations were expressed as percentage of injected dose $(\% \mathrm{ID}=$ activity $(\mathrm{Bq} / \mathrm{g}$ tissue $) /$ injected dose $(\mathrm{Bq}))$ or as standard uptake value $(\mathrm{SUV}=$ activity $(\mathrm{Bq} / \mathrm{g}$ tissue $) *$ body weight $(\mathrm{g}) /$ injected dose $(\mathrm{Bq})$ ).

Mice included in the PET experiment were given $0.5 \%$ $\mathrm{NaI}$ in their drinking water 1 day prior to the injection of the radioligand to reduce thyroidal uptake of I-124. Mice were injected with $10.7 \pm 2.1 \mathrm{MBq}\left[{ }^{124} \mathrm{I}\right] \mathrm{mAb} 1729-\mathrm{scFv} \mathrm{D} 3_{\mathrm{CL}}(1.3$ $\mathrm{MBq} / \mu \mathrm{g}$ ). After the injection, $\mathrm{NaI}$ concentration in the drinking water was decreased to $0.2 \% \mathrm{NaI}$. Blood samples, $8 \mu \mathrm{l}$, were obtained at $1 \mathrm{~h}, 3 \mathrm{~h}, 24 \mathrm{~h}$, and $72 \mathrm{~h}$ after injection. 
Mice were PET scanned in pairs, one ArcSwe and one WT, at $24 \mathrm{~h}, 48 \mathrm{~h}$, and $72 \mathrm{~h}$ after injection. Animals were anesthetized with $3 \%$ sevoflurane or $1.8 \%$ isoflurane and PET scanned for $60 \mathrm{~min}$ either in a preclinical nanoScan PET/MRI system (Mediso Medical Imaging Systems, Budapest, Hungary) followed by a CT in a preclinical SPECT/CT (Mediso) or in a Triumph Trimodality System (TriFoil Imaging Inc., Chatsworth, USA). Images from the Mediso system were reconstructed using a Tera-Tomo ${ }^{\mathrm{TM}} 3 \mathrm{D}$ algorithm (Mediso) with 4 iterations and 6 subsets. Data obtained with the Triumph system were reconstructed using a 3-dimensional ordered-subsets expectations maximization with 20 iterations.

All subsequent processing of the images was performed with Amide version 1.0.4 [28]. PET and CT scans were manually aligned with a T2-weighted mouse brain atlas [29] to quantify activity in regions of interest (Supplementary Fig. 1). Brain regions used for analysis were cortex, thalamus, caudate, and hippocampus. The area under the brain concentration curve (AUC) based on the three PET scans at $24 \mathrm{~h}, 48 \mathrm{~h}$, and $72 \mathrm{~h}$ post injection was calculated for each animal and each region of interest.

\section{Brain Tissue Extraction}

After isolation, brains were immediately dissected in halves. The cerebellum of the left hemisphere was separated from the cerebrum, and both parts (from now on called cerebellum and brain) were directly frozen for later tissue extraction. The right hemisphere was frozen for sectioning and subsequent immunohistochemistry and autoradiography analysis. Radioactivity in the different brain tissue samples (right hemisphere, brain and cerebellum) and blood was measured. Brain and cerebellum of the left hemisphere were homogenized separately with a Precellys Evolution (VWR, Stockholm, Sweden) $(4 \times 10 \mathrm{~s}$ at $5500 \mathrm{rpm})$ at a $1: 5$ weight/ volume ratio in Tris-buffered saline (TBS) with complete protease inhibitor (Sigma). After centrifugation, $1 \mathrm{~h}$ at 16 $000 \mathrm{~g}$, the supernatant was immediately removed and frozen.

\section{ELISA}

Soluble $A \beta$ protofibrils in brain TBS extracts were analyzed with a homogenous sandwich ELISA based on the $A \beta \mathrm{N}$ terminal specific antibody 3D6 [30]. 96-well plates were incubated with 3D6 antibody (in house produced as described previously [22]) with $50 \mathrm{ng}$ per well over night at $4{ }^{\circ} \mathrm{C}$. Plates were blocked for $2 \mathrm{~h}$ with $1 \%$ BSA. Brain extracts were incubated overnight at $4{ }^{\circ} \mathrm{C}$ followed by incubation with biotinylated 3D6 for $2 \mathrm{~h}$. After 1-h incubation with streptavidin-HRP (Mabtech AB, Nacka strand, Sweden), signals were developed with K-blue Aqueous TMB substrate (LumiraDx) and read with a spectrophotometer at $450 \mathrm{~nm}$.
sTREM2 levels in brain TBS extracts were analyzed using a sandwich ELISA [10]. Plates were coated with AF1729 (R\&D) (20 ng per well) overnight at $4{ }^{\circ} \mathrm{C}$ followed by 2 -h blocking with $1 \%$ BSA. Brain extracts were further diluted 80 times and incubated overnight at $4{ }^{\circ} \mathrm{C}$. Biotinylated BAF1729 (R\&D) was used as a secondary antibody for $2 \mathrm{~h}$ followed by streptavidin-HRP conjugate (Mabtech $\mathrm{AB}$ ) for $1 \mathrm{~h}$. Signals were developed and read as above.

The A $\beta$ and sTREM2 levels were also determined in brain extracts from all animals administered with the novel radioligand as well as in extracts obtained from a group of ArcSwe mice of different ages that were included to investigate the age or BACE-1 treatment related changes in the brain concentrations of these two proteins (Sup. Table 1).

\section{Autoradiography}

Animals administered with similar amount of $\left[{ }^{125} \mathrm{I}\right] \mathrm{mAb} 1729-\mathrm{scFv} 8 \mathrm{D} 3_{\mathrm{CL}}$ were selected for autoradiography. One day after isolation of the brain, right hemispheres were cyrosectioned $(40 \mu \mathrm{m})$ with a CM 1850 (Leica biosystems, Mölndal, Sweden). Sections were exposed to a phosphor screen in an X-ray cassette (PerkinElmer) for 16 days. The phosphor screen was read with a Cyclone Plus Imager system (PerkinElmer) at a resolution of $300 \mathrm{dpi}$. Further image processing was done with ImageJ software version 1.52a. Images were compiled with Photoshop 2020 (Adobe, San Jose, USA).

\section{Immunohistochemistry and Nuclear Track Emulsion}

Sections from fresh frozen right hemisphere tissue were fixed for $20 \mathrm{~min}$ in $4 \%$ paraformaldehyde in PBS. Antigens were retrieved by boiling the tissue for $5 \mathrm{~s}$ in $25 \mathrm{mM}$ sodium citrate at $\mathrm{pH} 6$ followed by cooling down for $20 \mathrm{~min}$. Slides were washed with PBS-TritonX100 $0.4 \%$ (Sigma) for $10 \mathrm{~min}$ and blocked with M.O.M basic kit (BioNordika) with $5 \%$ normal goat serum (BioNordika) for $1 \mathrm{~h}$. Primary antibodies (Aß: 6E10, Nordic Biosite; Anti-Iba-1: Wako chemicals; Täby, Sweden; Anti-GFAP: Abcam, Cambridge, UK) were applied in PBS. Antibodies were incubated over night at $4{ }^{\circ} \mathrm{C}$ on a shaker. Alexa-conjugated secondary antimouse, anti-rabbit, and anti-chicken antibodies (Thermo Fisher, Stockholm, Sweden) in $0.1 \%$ Tween 20 were applied for $2 \mathrm{~h}$ at room temperature (RT) as secondary antibodies.

\section{Nuclear Track Emulsion Autoradiography}

Nuclear track emulsion autoradiography (NTE) was performed after immunohistochemistry according to the producer's instructions (Ilford, Oxford, UK) as previously described [11]. In short, all experimental steps and storage were done in complete darkness. Slides were dipped in $50 \%$ 
Ilford K5 emulsion in water for $5 \mathrm{~s}$. Slides were dried for $2 \mathrm{~h}$ at RT and stored for 6 weeks at $4{ }^{\circ} \mathrm{C}$. Slides were developed in Ilford Phenisol for $4 \mathrm{~min}$ at a solution temperature of 18 ${ }^{\circ} \mathrm{C}$. The reaction was stopped with Ilford Ilfostop for $1 \mathrm{~min}$. Slides were fixed for 4 min in Ilford Hypam and washed for $10 \mathrm{~min}$ in water. Slides were mounted with Biotium Everbrite mounting media (BioNordika). Pictures were taken with a Zeiss LSM700 confocal laser scanning microscope (Carl Zeiss AB, Stockholm, Sweden) and processed with ZenZeiss software (Carl Zeiss AB).

\section{Statistical Analysis}

Data was analyzed with GraphPad Prism 6 (GraphPad Software, San Diego, USA). Groups were analyzed by non-parametric $t$-test, and multiple comparisons were performed with one-way ANOVA using Bonferroni's post hoc test or Dunnet's post hoc test. Average PET-based AUCs in the four regions of interests were ranked and compared using a non-parametric Mann-Whitney test. Results are reported as averages and standard deviation: ${ }^{*} p<0.05,{ }^{*} p<0.01$, $* * * p<0.001$, and $* * * * p<0.0001$.

\section{Results}

\section{TREM2 Levels Increase with Age}

sTREM2 and A $\beta$ protofibril concentrations were determined in the TBS soluble fraction of homogenates prepared from brains isolated from ArcSwe mice of different ages: 6-7, 10, 13, 16, 18, and 20 months (Fig. 2a-b). sTREM2 levels increased with age and correlated closely with $A \beta$ protofibrils (Fig. 2c). A large increase of both of these proteins was observed between the age of 13 and 18 months, while the concentrations then appeared to level out between 18 and 20 months. Brain tissue isolated from ArcSwe mice that had received the anti-A $\beta$ drug NB360 [31] (BACE-1 inhibitor) with confirmed reduction of $A \beta$ pathology [27] displayed reduced sTREM2 brain concentrations compared to littermates that did not receive NB360. This provided further mechanistic evidence of the strong correlation between $A \beta$ and sTREM2 (Fig. 2d).

\section{Generation of a Bispecific Antibody-Based Radioligand for TREM2}

Anti-TREM2 antibody mAb1729 was linked to the TfR binding $\mathrm{scFv} 8 \mathrm{D} 3_{\mathrm{CL}}$ by chemical conjugation between a TCO group attached to mAb1729 and a tetrazine group attached to $\mathrm{scFv} 8 \mathrm{D} 3_{\mathrm{CL}}$. After fusion, both binding moieties, i.e., scFv8D $3_{\mathrm{CL}}$ and $\mathrm{mAb} 1729$, remained functional and bound to their targets, i.e., TfR and TREM2, respectively (Fig. 3a). The bispecific construct was then radiolabeled with I-125, and functionality of the radioligand was investigated both in vitro and in vivo. The binding affinity to both TfR and TREM2 was decreased somewhat after radiolabeling (Fig. 3a). However, when administered to WT mice, the brain concentrations at $2 \mathrm{~h}$ were around $0.4 \%$ of injected dose per gram brain tissue (\%ID/g) (Fig. 3b) which is in line with what has been reported for similar constructs previously [11] and thus indicated that the $s c F v 8 D 3_{C L}$ binding moiety remained functional also after radiolabeling.

To study TREM2 levels in vivo, $\left[{ }^{125} \mathrm{I}\right] \mathrm{mAb} 1729$ scFv8D $3_{\mathrm{CL}}$ was administered intravenously to 18-20month-old transgenic ArcSwe, Swe, and WT mice. Following administration, the radioligand was cleared from the blood with an estimated half-life of about $13 \mathrm{~h}$ (Fig 3d, Supplementary Fig. 2a). Brain concentration of $\left[{ }^{125} \mathrm{I}\right] \mathrm{mAb} 1729-\mathrm{scFv} 8 \mathrm{D} 3_{\mathrm{CL}}$ in isolated brains was measured at $24 \mathrm{~h}$ and $72 \mathrm{~h}$ post injection and expressed as \% ID/g (Fig. $3 \mathrm{~b}$ ) or as SUV (Fig. 3c). At $24 \mathrm{~h}$ post injection, $\left[{ }^{125} \mathrm{I}\right] \mathrm{mAb} 1729-\mathrm{scFv} 8 \mathrm{D} 3_{\mathrm{CL}}$ brain concentrations were $29 \%$ higher in ArcSwe animals $(p=0.042)$ and $30 \%$ higher in Swe animals $(p=0.036)$ compared to WT, when expressed as $\% \mathrm{ID} / \mathrm{g}$. When expressed as SUV, brain concentrations were $23 \%$ higher in ArcSwe $(p=0.029)$ and $19 \%$ higher in Swe mice $(p=0.049)$ compared to WT. At $72 \mathrm{~h}$ post injection, neither of the transgenic models showed significantly different $\left[{ }^{125} \mathrm{I}\right] \mathrm{mAb} 1729-\mathrm{scF} 8 \mathrm{D} 3_{\mathrm{CL}}$ concentrations $(p>0.05)$ compared to WT. However, there was a trend that the transgenic animals also at this time point showed elevated $\left[{ }^{125} \mathrm{I}\right] \mathrm{mAb} 1729-\mathrm{scFv} 8 \mathrm{D} 3_{\mathrm{CL}}$ brain concentrations compared to WT (Fig. 3b-c). sTREM2 concentrations determined in brain homogenates with ELISA were elevated in ArcSwe mice in comparison to both Swe and WT (Fig. 3e). Swe mice also displayed higher sTREM2 brain concentrations than WT mice (Fig. 3e).

\section{In Vivo PET and Ex Vivo Autoradiography Imaging of TREM2}

ArcSwe and WT mice were scanned at $24 \mathrm{~h}, 48 \mathrm{~h}$, and $72 \mathrm{~h}$ post $\left[{ }^{124} \mathrm{I}\right] \mathrm{mAb} 1729-\mathrm{scFv} 8 \mathrm{D} 3_{\mathrm{CL}}$ injection. Brain concentrations of $\left[{ }^{124} \mathrm{I}\right] \mathrm{mAb} 1729-\mathrm{scFv} 8 \mathrm{D} 3_{\mathrm{CL}}$ were quantified as SUV in cortex, thalamus, caudate, hippocampus, and the whole brain (Fig. 4a). Although not reaching statistical significance, ArcSwe mice tended to display higher SUVs at all time points in all investigated regions. To estimate the brain exposure over time, the area under the concentration curve $\left(\mathrm{AUC}_{24-72} \mathrm{~h}\right)$ was calculated for all sub-regions. When ranked, AUCs in all four investigated sub-regions in ArcSwe mice were larger than the AUCs calculated in the WT mice (Fig. 4b, Supplementary Fig. 2b).

Radioligand concentrations in liver, spleen, heart, lung, kidney, pancreas, and urine after the $72 \mathrm{~h}$ scan were quantified ex vivo after perfusion. The concentration of $\left[{ }^{124} \mathrm{I}\right] \mathrm{mAb} 1729-\mathrm{scFv} 8 \mathrm{D} 3_{\mathrm{CL}}$ in these organs were not significantly different between ArcSwe and WT mice (Fig. 4c, Supplementary Fig. 2c). In line with the single time point 

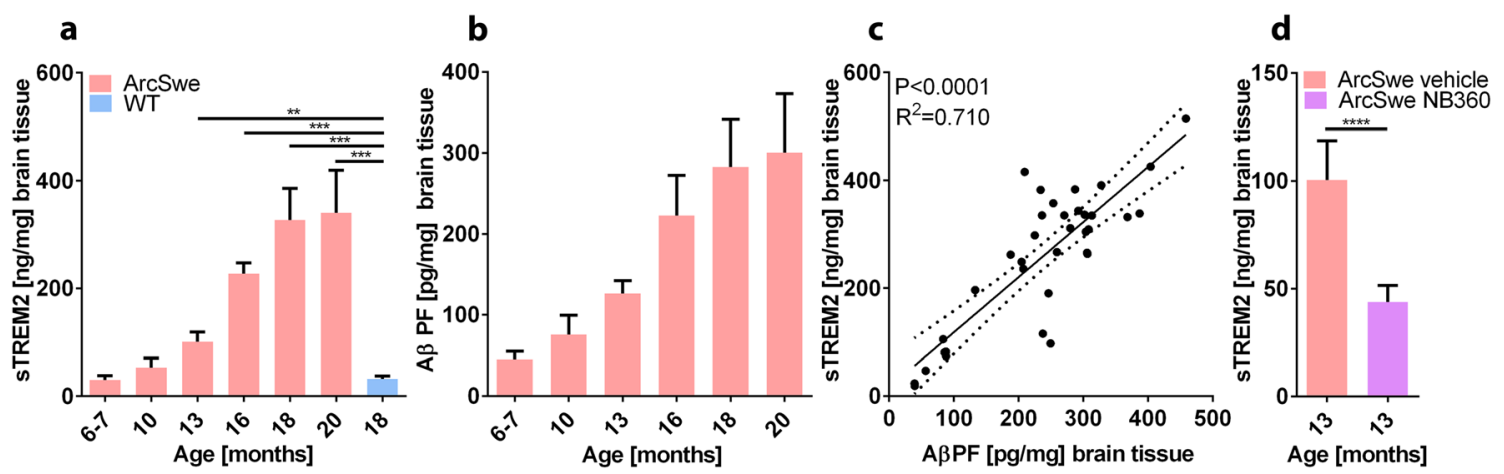

Fig. 2 Analysis of homogenized post mortem brain tissue obtained from ArcSwe mice of different ages. (a) sTREM2 concentrations in TBS brain extracts in age groups 6-7 months $(n=7), 10$ months $(n=8), 13$ months $(n=8), 16$ months $(n=5), 18$ months ( $n=11), 20$ months ( $n=14$ ), and wild-type (WT) 18 months old ( $n=18)$. (b) A $\beta$ protofibril (PF) concentrations in TBS brain extracts in the same age groups (except WT as they do not express human A $\beta$ ). (c) Correlation between sTREM2 and A $\beta$ protofibril concentration. (d) Decreased sTREM2 levels in mice treated with BACE-1 inhibitor NB360 (n=9) compared to vehicle treated animals $(n=8)$ at the age of 13 months.

a
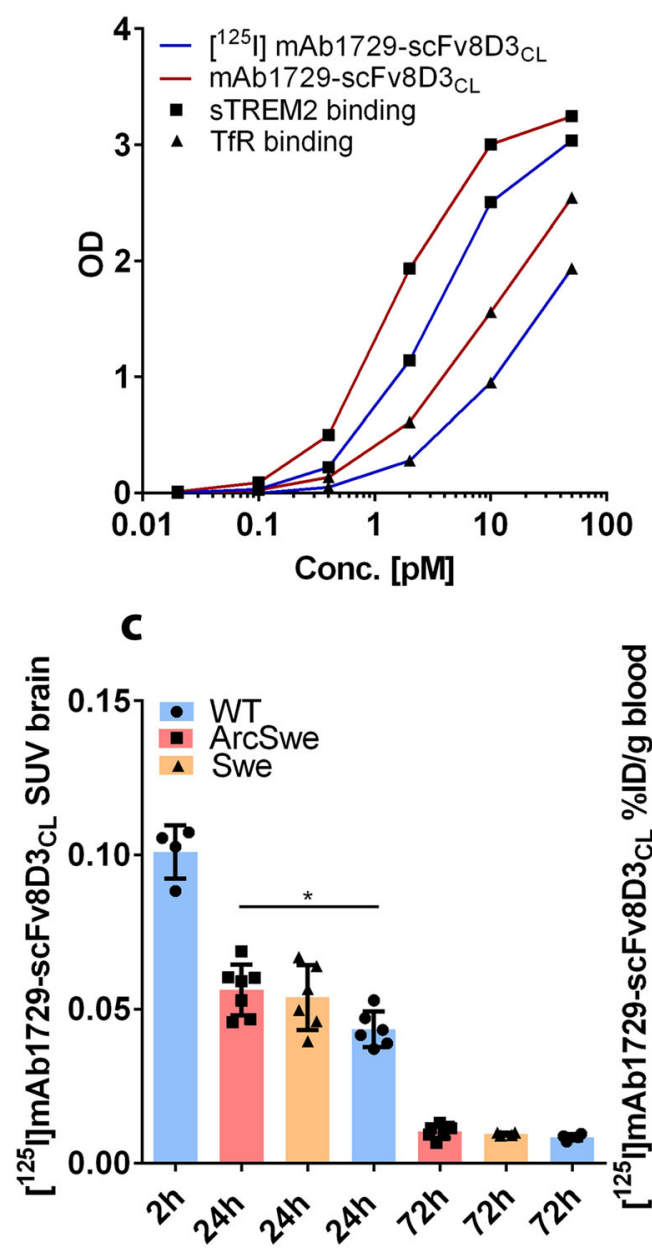
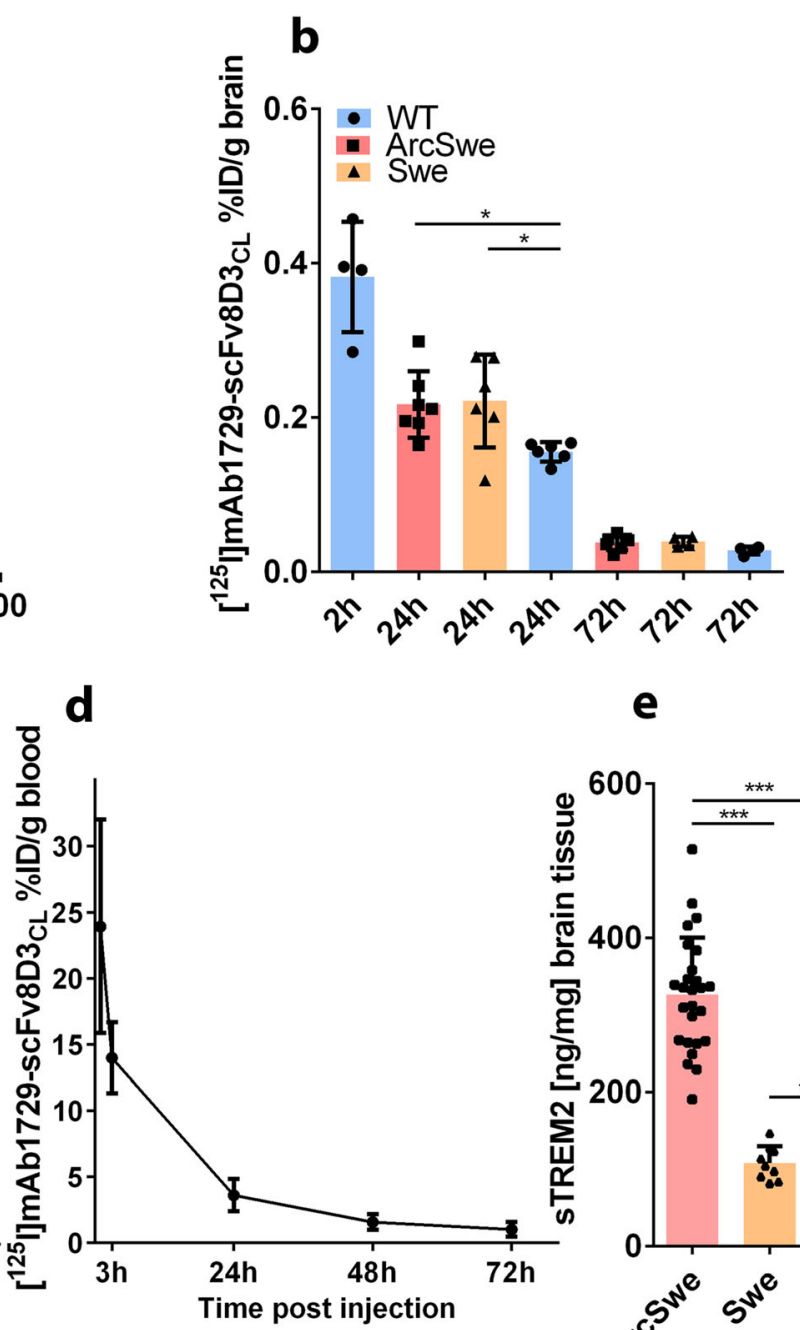

e

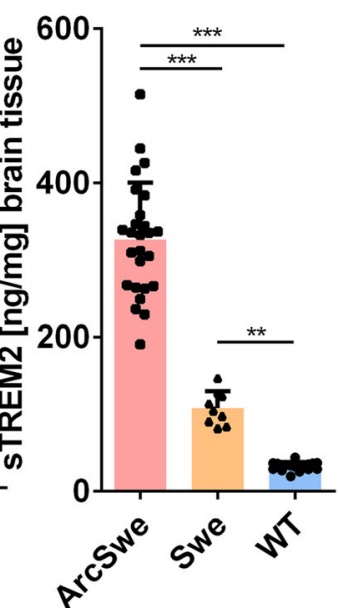

Fig. 3 (a) Binding comparison of I-125 labeled and unlabeled mAb1729-scFv8D3 ${ }_{C L}$ in ELISA. (b) Percent of injected dose and standard uptake value (SUV) (c) of $\left.{ }^{125} \mathrm{l}\right] \mathrm{mAb} 1729-\mathrm{scFv} 8 \mathrm{D} 3_{\mathrm{CL}}$ in brain $2 \mathrm{~h}, 24 \mathrm{~h}$, and $72 \mathrm{~h}$ after injection. (d) Blood was sampled $1 \mathrm{~h}, 3 \mathrm{~h}, 24 \mathrm{~h}, 48 \mathrm{~h}$, and $72 \mathrm{~h}$ after injection. (e) sTREM2 levels in TBS extracted brains of ArcSwe, Swe, and WT mice at the age of 18 months. 

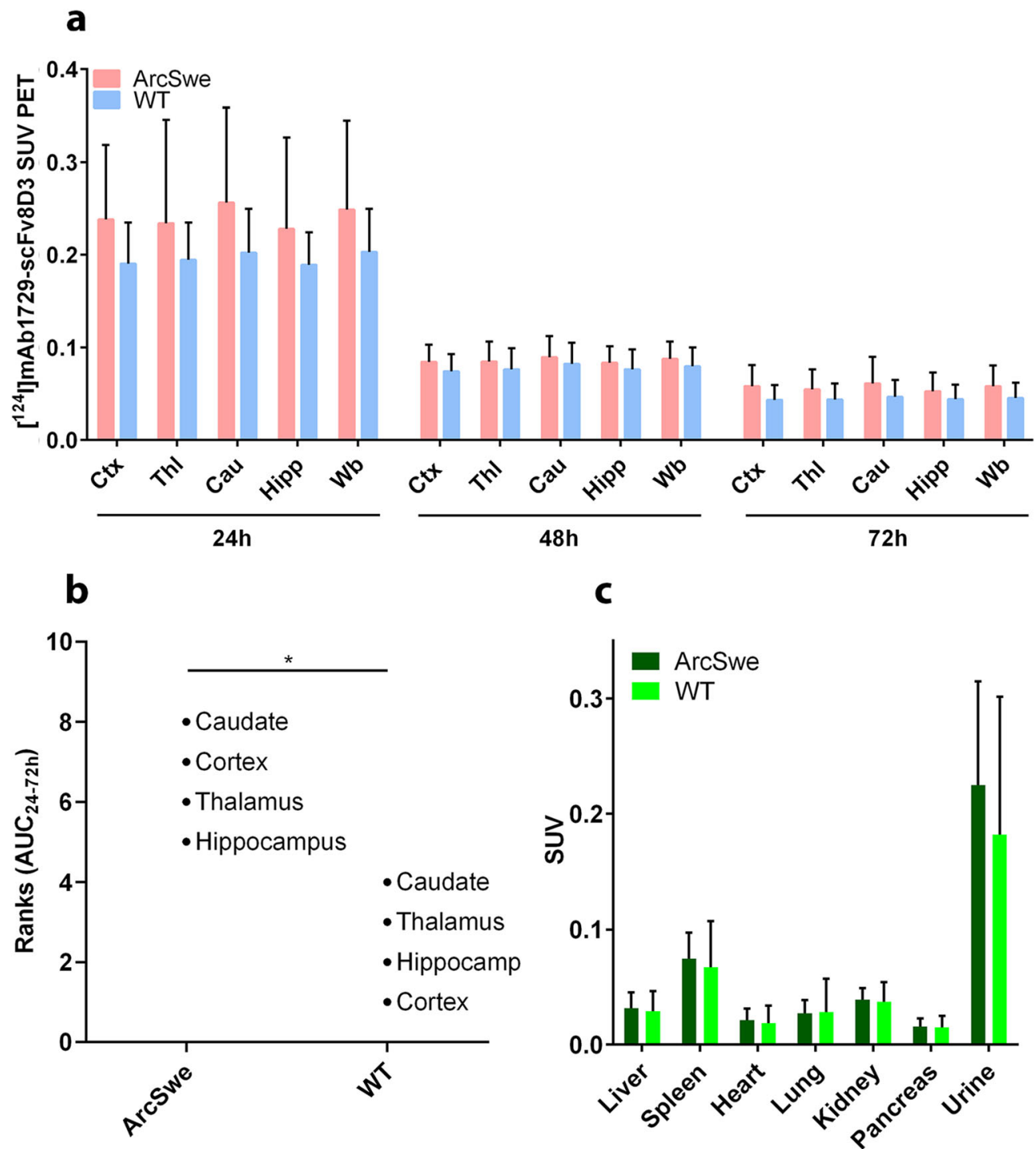

Fig. 4 (a) Quantification, expressed as SUV, of the radioligand $\left[{ }^{124} \mathrm{l}\right] \mathrm{mAb} 1729-\mathrm{scFv} 8 \mathrm{D} 3_{\mathrm{CL}}$ in cortex (Ctx), thalamus (Thl), caudate (Cau), hippocampus (Hipp), and the whole brain (Wb) with PET at $24 \mathrm{~h}, 48 \mathrm{~h}$, and $72 \mathrm{~h}$ after injection in ArcSwe $(n=8)$ and WT (n=8). (b) Ranks of AUC, calculated between $24 \mathrm{~h}$ and $72 \mathrm{~h}$. Caudate in ArcSwe displayed the highest exposure of the radioligand, while cortex in WT showed the lowest exposure. (c) Biodistribution of $\left.{ }^{124} \mathrm{I}\right] \mathrm{mAb} 1729-\mathrm{scFv} 8 \mathrm{D} 3_{\mathrm{CL}}$ in organs and urine of ArcSwe and WT mice. No difference was observed in the peripheral distribution between ArcSwe and WT.

brain SUVs, PET images did not reveal any visual difference between ArcSwe and WT mice (Fig. 5a).

Autoradiography was performed on brain sections prepared from the right hemisphere of the perfused brains to study the spatial distribution of $\left[{ }^{125} \mathrm{I}\right] \mathrm{mAb} 1729-\mathrm{scFv} 8 \mathrm{D} 3_{\mathrm{CL}}$ within the brain tissue without radioactivity from the brain blood volume (which is included in the signal in vivo with PET). The intensity of the signal appeared to be higher in ArcSwe and Swe compared with WT animals in sections obtained from animals perfused at $24 \mathrm{~h}$ (Fig. 5b and Supplementary Fig. 3). In particular, ArcSwe and Swe animals displayed increased retention of $\left[{ }^{125} \mathrm{I}\right] \mathrm{mAb} 1729$ scFv8D $3_{C L}$ in cortex and thalamus, two regions known to contain high levels of $A \beta$, compared to other regions.
Although the signal at $72 \mathrm{~h}$ was low, there was still a visually detected increased signal in cortex of ArcSwe animals.

\section{Immunohistochemistry and Nuclear Track Emulsion (NTE)}

Brains sections from ArcSwe animals were stained for Iba-1, GFAP, and $A \beta$ to map activated microglia and astrocytes in connection with A $\beta$ plaque pathology (Fig. 6, Supplementary Fig. 4). NTE was performed on the stained sections in order to visualize the retention of $\left[{ }^{125} \mathrm{I}\right] \mathrm{mAb} 1729-\mathrm{scFv} 8 \mathrm{D} 3_{\mathrm{CL}}$ in the tissue. Cortex and 


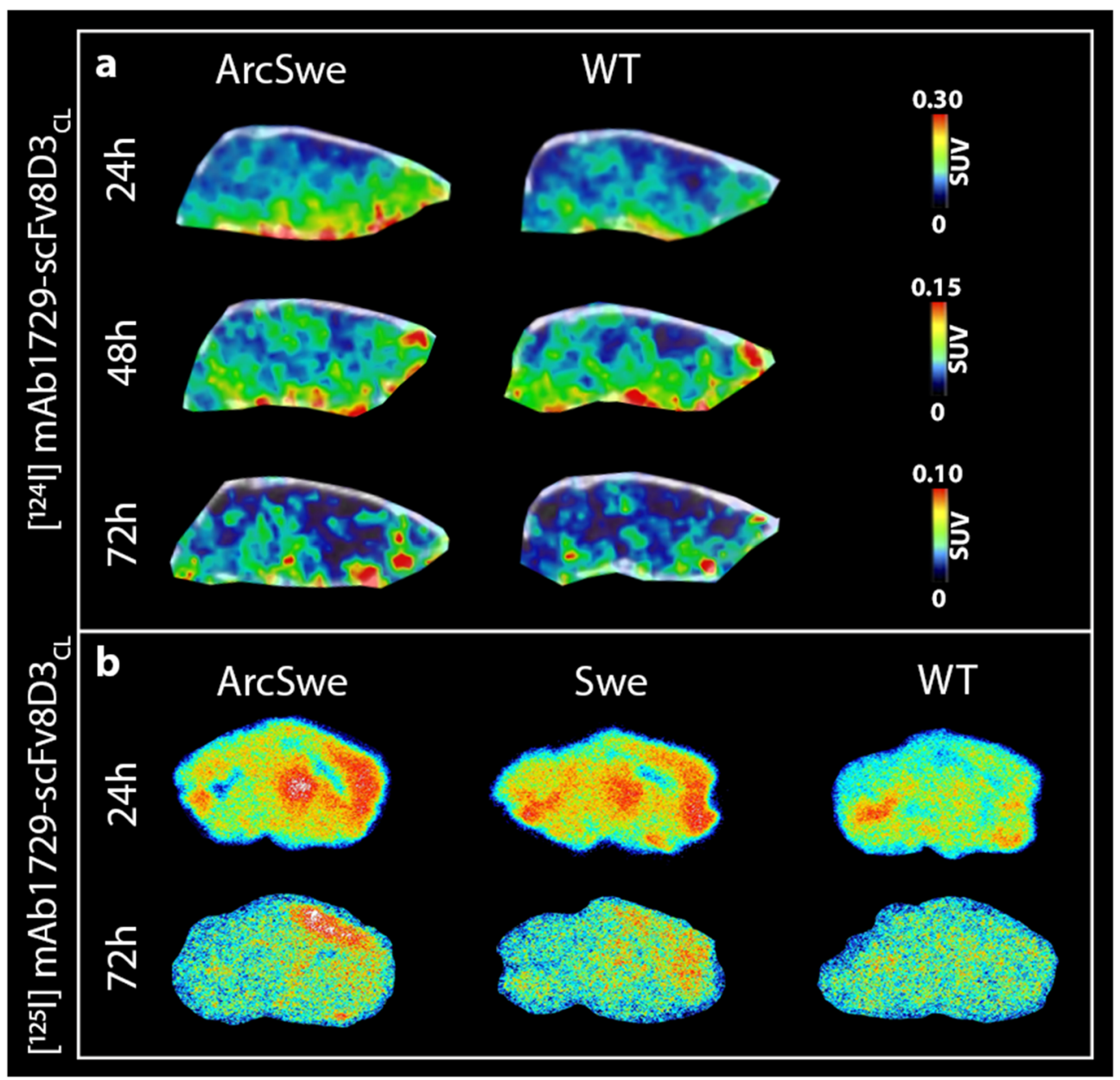

Fig. 5 Representative SUV scaled sagittal PET images with $\left[{ }^{124} \mathrm{I}\right] \mathrm{mAb} 1729-\mathrm{scFv8D} 3_{\mathrm{CL}}$. ArcSwe animals, compared to WT animals at $24 \mathrm{~h}, 48 \mathrm{~h}$, and $72 \mathrm{~h}$ after injection (a). Radioligand distribution in brain tissue displayed in sagittal ex vivo autoradiography images in ArcSwe, Swe, and WT animals at $24 \mathrm{~h}$ and $72 \mathrm{~h}$ after injection (b).

thalamus were chosen because of high $A \beta$ load and high retention of the radioligand on autoradiography images. At $24 \mathrm{~h}$ after injections, $\left[{ }^{125} \mathrm{I}\right] \mathrm{mAb} 1729-\mathrm{scFv} 8 \mathrm{D} 3_{\mathrm{CL}}$ was found in the vicinity of $A \beta$ plaques and activated glial cells. However, the antibody did not appear to co-localize with astrocytes and only partly with microglia. At $72 \mathrm{~h}$ after injection, the radioligand was more equally distributed throughout the whole tissue, and there was no longer a pattern of high concentration of $\left[{ }^{125} \mathrm{I}\right] \mathrm{mAb} 1729-\mathrm{scFv} 8 \mathrm{D} 3_{\mathrm{CL}}$ in association to $A \beta$ plaques.

\section{Discussion}

In this study, we designed and generated a bispecific, brainpenetrant antibody and used it to assess TREM2 levels in two different mouse models of $A \beta$ pathology.

Since the first investigations two decades ago, upregulated TSPO levels have been the center of attention for studies of microglial activation in vivo with PET. However, the development of radioligands for activated microglia has turned out to be challenging. The first and most frequently used PET radioligand $\left[{ }^{11} \mathrm{C}\right] \mathrm{PK} 11195$ is associated with problems such as high plasma protein binding, low extraction fraction to the brain, and limited specific-tobackground ratios $[32,33]$. The use of later generations of TSPO PET radioligands is hampered by a nucleotide polymorphism in the TSPO gene that affects binding [34]. Third-generation radioligands, such as $\left[{ }^{18} \mathrm{~F}\right] \mathrm{GE} 180$, are currently under intense research and seem, in line with the second generation of radioligands, to be affected by polymorphisms although to a lesser degree. Similar to $\left[{ }^{11} \mathrm{C}\right] \mathrm{PK} 11195$, low first-pass extraction rate and a large blood component have been observed also for the more recently developed TSPO radioligands [35]. Further, and regardless of radioligand generation, TSPO is not specific for microglia but also expressed on astrocytes and endothelial cell as well as on peripheral cells of myeloid lineage [36, 37]. Thus, alternatives to TSPO for imaging of microglial activation are needed. One such alternative could be imaging if TREM2. The radioligand $\left[{ }^{125} \mathrm{I}\right] \mathrm{mAb} 1729-\mathrm{scFv} 8 \mathrm{D} 3_{\mathrm{CL}}$, described in the present study, enters the brain by TfR mediated transcytosis across the BBB. The brain 


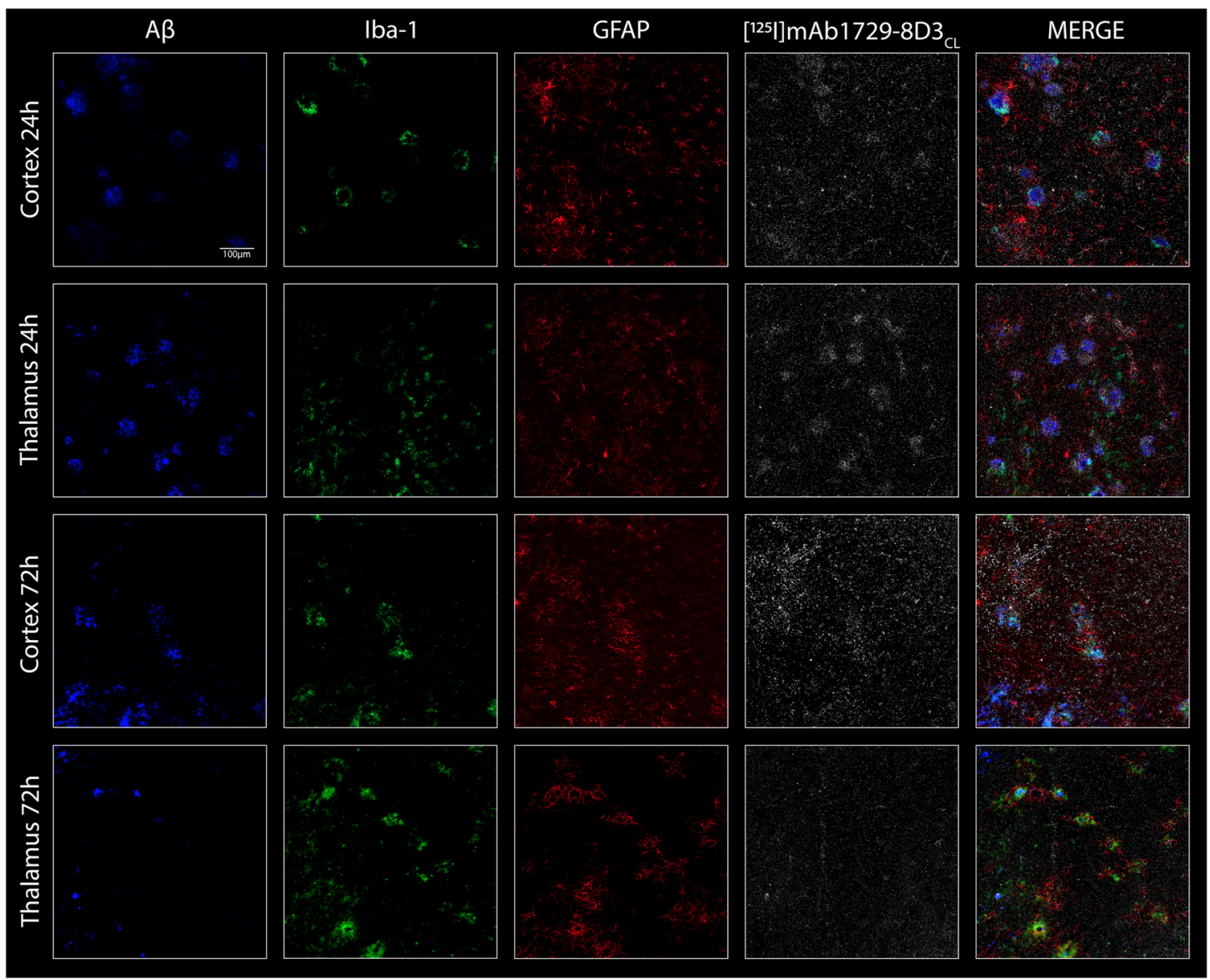

Fig. 6 Immunohistochemistry and nuclear track emulsion. Tissue was stained for A 3 , Iba-1, and GFAP on sections prepared from perfused and snap-frozen ArcSwe brains $24 \mathrm{~h}$ and $72 \mathrm{~h}$ post injection of $\left[{ }^{125} \mathrm{l}\right] \mathrm{mAb} 1729$-scFv8D3 $\mathrm{CL}$. Nuclear track emulsion visualizes the retention of $\left[{ }^{125} \mathrm{I}\right] \mathrm{mAb} 1729-\mathrm{scFv} 8 \mathrm{D} 3_{\mathrm{CL}}$ in the tissue, white dots represent radiolabeled antibody.

concentrations at 1 day after administration were comparable to what has been described previously for bispecific constructs based on TfR and $A \beta$ targeting antibodies [11]. Similar to the bispecific radioligands for different $A \beta$ species, the new radioligand for TREM2, $\left[{ }^{125} \mathrm{I}\right] \mathrm{mAb} 1729$ scFv8D $3_{\mathrm{CL}}$, showed increased brain retention in transgenic mice compared to wild-type mice at 1 day post injection. These results were in line with sTREM2 levels measured in post mortem brain tissue by ELISA.

However, with PET, the study failed to clearly visualize and quantify differences between transgenic and WT mice in vivo at a single time point ( $24 \mathrm{~h}, 48 \mathrm{~h}$, or $72 \mathrm{~h})$, despite the convincing differences in sTREM2 brain concentrations. One difference between in vivo PET and ex vivo ELISA detection is, as discussed previously, the presence of membrane bound TREM 2 in vivo. Thus, in theory, the methods may detect slightly different "pools" of TREM2. Still, autoradiography as well as NTE indicated that the radioligand was present at higher levels in mice with $\mathrm{A} \beta$ pathology compared to WT. These observations were also supported by the AUC comparisons between transgenic and WT mice based on PET measurement on multiple days (24-
$72 \mathrm{~h}$ ). One obvious challenge with antibodies as PET radioligands is their long residence time in blood. Since 3 $\%$ of the brain volume is blood [38], a high signal in blood will mask the signal from the brain parenchyma. In the present study, when blood was removed, as in ex vivo autoradiography, differences between transgenic and WT animals became visible already at $24 \mathrm{~h}$ post injection. Thus, a facilitated clearance could enable in vivo visualization at this time point. Reducing the size of the bispecific construct has previously been shown to increase the rate of elimination [14]. Scanning at a later time point, when blood concentrations have decreased, is also a possibility if the radioligand is retained at its intrabrain target. In the present study, however, it appeared that the radioligand, or potentially the radioligand bound to sTREM2, was not retained in the brain over a longer period of time. Radioligand concentrations decreased from $0.38 \% \mathrm{ID} / \mathrm{g}$ at $2 \mathrm{~h}$ to $0.21 \% \mathrm{ID} / \mathrm{g}$ already at $24 \mathrm{~h}$ post injection. Compared to previous bispecific constructs targeting $A \beta$, the initial concentrations are similar, but for $\mathrm{A} \beta$ directed constructs, concentrations as low as 0.2 $\% \mathrm{ID} / \mathrm{g}$ are not reached until $72 \mathrm{~h}$ post injection in transgenic mice [11]. One possible explanation for this striking 
difference may be the nature of the target. STREM2 is soluble and highly diffusible and might be removed from the brain at a higher rate than large $A \beta$ aggregates. The binding of $\mathrm{mAb} 1729-\mathrm{scFv} 8 \mathrm{D} 33_{\mathrm{CL}}$ to sTREM2 or potentially to membrane bound TREM2 could facilitate the clearance. NTE also showed that less mAb1729-scFv8D $3_{C L}$ appeared to be localized in vicinity of the plaques at a later time point. Yet another possibility is that the binding affinity of $\mathrm{mAb} 1729-\mathrm{scFv} 8 \mathrm{D} 3_{\mathrm{CL}}$ to TREM2 or sTREM2 is not sufficient to retain the antibody. Thereby, in line with the process in the WT brain, unbound $\mathrm{mAb} 1729-\mathrm{scFv} 8 \mathrm{D} 3_{\mathrm{CL}}$ is cleared from the brain parenchyma. Thus, antibodies with higher affinity for TREM2 could result in improved PET quantification. As TREM2 is a new disease target, the availability of antibodies was limited at the start of the present study, but new antibodies are appearing [39].

In conclusion, $\left[{ }^{125} \mathrm{I}\right] \mathrm{mAb} 1729-\mathrm{scFv} 8 \mathrm{D} 3_{\mathrm{CL}}$ was shown to be a useful tool to detect TREM2 ex vivo. The study showed that antibody-based PET imaging of TREM2 is a possibility, but antibody formats that are cleared faster from blood and antibodies showing higher affinity for TREM2 must be developed to further progress this technique for in vivo use.

Supplementary Information. The online version contains supplementary material available at https://doi.org/10.1007/s11307-021-01591-3.

Acknowledgements. We thank Professor Lars Nilsson for developing the mouse models used in this study. The funding bodies did not take part in design of the study, in collection, analysis, or interpretation of data, nor in writing the manuscript. The molecular imaging work in this study was performed at the SciLifeLab Pilot Facility for Preclinical PET-MRI, a Swedish nationally available imaging platform at Uppsala University, Sweden, financed by the Knut and Alice Wallenberg Foundation.

Funding. Open access funding provided by Uppsala University. This study was funded by the Swedish Research Council (2017-02413, 2018-02715), Alzheimerfonden, Hjärnfonden, Torsten Söderbergs stiftelse, Åhlénstiftelsen, Magnus Bergwalls stiftelse, Stiftelsen för gamla tjänarinnor, Konung Gustaf V:s och Drottning Victorias Frimuarestiftelse, and Stohnes stiftelse.

\section{Declarations}

\section{Ethics approval}

All applicable institutional and/or national guidelines for the care and use of animals were followed. The experiments were approved by The Uppsala Country Animal Ethics board (approval 5.8.18-13350/2017).

\section{Conflict of Interest}

The authors declare that they have no conflict of interest.

Open Access This article is licensed under a Creative Commons Attribution 4.0 International License, which permits use, sharing, adaptation, distribution and reproduction in any medium or format, as long as you give appropriate credit to the original author(s) and the source, provide a link to the Creative Commons licence, and indicate if changes were made. The images or other third party material in this article are included in the article's Creative Commons licence, unless indicated otherwise in a credit line to the material. If material is not included in the article's Creative Commons licence and your intended use is not permitted by statutory regulation or exceeds the permitted use, you will need to obtain permission directly from the copyright holder. To view a copy of this licence, visit http:// creativecommons.org/licenses/by/4.0/.

\section{References}

1. Ziegler-Graham K, MacKenzie EJ, Ephraim PL, Travison TG, Brookmeyer R (2008) Estimating the prevalence of limb loss in the United States: 2005 to 2050. Arch Phys Med Rehabil 89:422-429

2. Heneka MT, Carson MJ, Khoury JE, Landreth GE, Brosseron F, Feinstein DL, Jacobs AH, Wyss-Coray T, Vitorica J, Ransohoff RM, Herrup K, Frautschy SA, Finsen B, Brown GC, Verkhratsky A, Yamanaka K, Koistinaho J, Latz E, Halle A, Petzold GC, Town T, Morgan D, Shinohara ML, Perry VH, Holmes C, Bazan NG, Brooks DJ, Hunot S, Joseph B, Deigendesch N, Garaschuk O, Boddeke E, Dinarello CA, Breitner JC, Cole GM, Golenbock DT, Kummer MP (2015) Neuroinflammation in Alzheimer's disease. Lancet Neurol 14:388-405

3. Butovsky O, Weiner HL (2018) Microglial signatures and their role in health and disease. Nat Rev Neurosci 19:622-635

4. Jay TR, von Saucken VE, Landreth GE (2017) TREM2 in Neurodegenerative diseases. Mol Neurodegener 12:56

5. Wunderlich P, Glebov K, Kemmerling N, Tien NT, Neumann H, Walter J (2013) Sequential proteolytic processing of the triggering receptor expressed on myeloid cells-2 (TREM2) protein by ectodomain shedding and $\gamma$-secretase-dependent intramembranous cleavage. J Biol Chem 288:33027-33036

6. Suárez-Calvet M, Kleinberger G, Araque Caballero MÁ, Brendel M, Rominger A, Alcolea D, Fortea J, Lleó A, Blesa R, Gispert JD, Sánchez-Valle R, Antonell A, Rami L, Molinuevo JL, Brosseron F, Traschütz A, Heneka MT, Struyfs H, Engelborghs S, Sleegers K, van Broeckhoven $\mathrm{C}$, Zetterberg $\mathrm{H}$, Nellgård $\mathrm{B}$, Blennow $\mathrm{K}$, Crispin $\mathrm{A}$, Ewers M, Haass C (2016) sTREM2 cerebrospinal fluid levels are a potential biomarker for microglia activity in early-stage Alzheimer's disease and associate with neuronal injury markers. EMBO Mol Med $8: 466-476$

7. Heslegrave A, Heywood W, Paterson R, Magdalinou N, Svensson J, Johansson P, Öhrfelt A, Blennow K, Hardy J, Schott J, Mills K, Zetterberg H (2016) Increased cerebrospinal fluid soluble TREM2 concentration in Alzheimer's disease. Mol Neurodegener 11:3

8. Piccio L, Deming Y, del-Águila JL, Ghezzi L, Holtzman DM, Fagan AM, Fenoglio C, Galimberti D, Borroni B, Cruchaga C (2016) Cerebrospinal fluid soluble TREM2 is higher in Alzheimer disease and associated with mutation status. Acta Neuropathol (Berl) 131:925-933

9. Richards JG, Higgins GA, Ouagazzal AM, Ozmen L, Kew JNC, Bohrmann B, Malherbe P, Brockhaus M, Loetscher H, Czech C, Huber G, Bluethmann H, Jacobsen H, Kemp JA (2003) PS2APP transgenic mice, coexpressing hPS2mut and hAPPswe, show agerelated cognitive deficits associated with discrete brain amyloid deposition and inflammation. J Neurosci 23:8989-9003

10. Brendel M, Kleinberger G, Probst F, Jaworska A, Overhoff F, Blume T, Albert NL, Carlsen J, Lindner S, Gildehaus FJ, Ozmen L, SuárezCalvet M, Bartenstein P, Baumann K, Ewers M, Herms J, Haass C, Rominger A (2017) Increase of TREM2 during aging of an Alzheimer's disease mouse model is paralleled by microglial activation and amyloidosis. Front Aging Neurosci 9:8

11. Sehlin D, Fang XT, Cato L, Antoni G, Lannfelt L, Syvänen S (2016) Antibody-based PET imaging of amyloid beta in mouse models of Alzheimer's disease. Nat Commun 7:10759

12. Syvänen S, Fang XT, Hultqvist G, Meier SR, Lannfelt L, Sehlin D (2017) A bispecific Tribody PET radioligand for visualization of amyloid-beta protofibrils - a new concept for neuroimaging. NeuroImage 148:55-63

13. Fang XT, Hultqvist G, Meier SR, Antoni G, Sehlin D, Syvänen S (2019) High detection sensitivity with antibody-based PET radioligand for amyloid beta in brain. NeuroImage 184:881-888

14. Sehlin D, Syvänen S (2019) \& MINC faculty. Engineered antibodies: new possibilities for brain PET? Eur J Nucl Med Mol Imaging 46:2848-2858

15. Sehlin D, Fang XT, Meier SR, Jansson M, Syvänen S (2017) Pharmacokinetics, biodistribution and brain retention of a bispecific antibody-based PET radioligand for imaging of amyloid- $\beta$. Sci Rep $7: 17254$ 
16. Sehlin D, Stocki P, Gustavsson T, Hultqvist G, Walsh FS, Rutkowski JL, Syvänen S (2020) Brain delivery of biologics using a cross-species reactive transferrin receptor 1 VNAR shuttle. FASEB J Off Publ Fed Am Soc Exp Biol 34:13272-13283. https://doi.org/10.1096/ fi.202000610RR

17. Lee HJ, Engelhardt B, Lesley J, Bickel U, Pardridge WM (2000) Targeting rat anti-mouse transferrin receptor monoclonal antibodies through blood-brain barrier in mouse. J Pharmacol Exp Ther 292:1048-1052

18. Kissel K, Hamm S, Schulz M, Vecchi A, Garlanda C, Engelhardt B (1998) Immunohistochemical localization of the murine transferrin receptor (TfR) on blood-tissue barriers using a novel anti-TfR monoclonal antibody. Histochem Cell Biol 110:63-72

19. Hultqvist G, Syvänen S, Fang XT, Lannfelt L, Sehlin D (2017) Bivalent brain shuttle increases antibody uptake by monovalent binding to the transferrin receptor. Theranostics 7:308-318

20. Syvänen S, Hultqvist G, Gustavsson T, Gumucio A, Laudon H, Söderberg L, Ingelsson M, Lannfelt L, Sehlin D (2018) Efficient clearance of $\mathrm{A} \beta$ protofibrils in $\mathrm{A} \beta \mathrm{PP}$-transgenic mice treated with a brain-penetrating bifunctional antibody. Alzheimers Res Ther 10:49

21. Hopp TP, Prickett KS, Price VL, Libby RT, March CJ, Pat Cerretti D, Urdal DL, Conlon PJ (1988) A short polypeptide marker sequence useful for recombinant protein identification and purification. Bio/ Technology 6:1204-1210

22. Fang XT, Sehlin D, Lannfelt L, Syvänen S, Hultqvist G (2017) Efficient and inexpensive transient expression of multispecific multivalent antibodies in Expi293 cells. Biol Proced Online 19:11

23. Luo H, Hernandez R, Hong H, Graves SA, Yang Y, England CG, Theuer CP, Nickles RJ, Cai W (2015) Noninvasive brain cancer imaging with a bispecific antibody fragment, generated via click chemistry. Proc Natl Acad Sci U S A 112:12806-12811

24. Greenwood FC, Hunter WM, Glover JS (1963) The preparation of 131I-labelled human growth hormone of high specific radioactivity. Biochem J 89:114-123

25. Lord A, Kalimo H, Eckman C, Zhang XQ, Lannfelt L, Nilsson LNG (2006) The Arctic Alzheimer mutation facilitates early intraneuronal $\mathrm{A} \beta$ aggregation and senile plaque formation in transgenic mice. Neurobiol Aging 27:67-77

26. Philipson O, Hammarström P, Nilsson KPR, Portelius E, Olofsson T, Ingelsson M, Hyman BT, Blennow K, Lannfelt L, Kalimo H, Nilsson LNG (2009) A highly insoluble state of Abeta similar to that of Alzheimer's disease brain is found in Arctic APP transgenic mice. Neurobiol Aging 30:1393-1405

27. Meier SR, Syvänen S, Hultqvist G, Fang XT, Roshanbin S, Lannfelt L, Neumann U, Sehlin D (2018) Antibody-based in vivo PET imaging detects amyloid- $\beta$ reduction in Alzheimer transgenic mice after BACE-1 inhibition. J Nucl Med Off Publ Soc Nucl Med 59:18851891. https://doi.org/10.2967/jnumed.118.213140

28. Andreas Markus Loening SSG (2003) AMIDE: a free software tool for multimodality medical image analysis. Mol Imaging 2:131-137

29. Ma Y, Hof PR, Grant SC, Blackband SJ, Bennett R, Slatest L, McGuigan MD, Benveniste H (2005) A three-dimensional digital atlas database of the adult $\mathrm{C} 57 \mathrm{BL} / 6 \mathrm{~J}$ mouse brain by magnetic resonance microscopy. Neuroscience 135:1203-1215

30. Bard F, Cannon C, Barbour R, Burke RL, Games D, Grajeda H, Guido T, Hu K, Huang J, Johnson-Wood K, Khan K, Kholodenko D, Lee M, Lieberburg I, Motter R, Nguyen M, Soriano F, Vasquez N, Weiss K, Welch B, Seubert P, Schenk D, Yednock T (2000) Peripherally administered antibodies against amyloid beta-peptide enter the central nervous system and reduce pathology in a mouse model of Alzheimer disease. Nat Med 6:916-919

31. Neumann U, Rueeger H, Machauer R, Veenstra SJ, Lueoend RM, Tintelnot-Blomley M, Laue G, Beltz K, Vogg B, Schmid P, Frieauff W, Shimshek DR, Staufenbiel M, Jacobson LH (2015) A novel BACE inhibitor NB-360 shows a superior pharmacological profile and robust reduction of amyloid- $\beta$ and neuroinflammation in APP transgenic mice. Mol Neurodegener 10:44

32. Lockhart A, Davis B, Matthews JC, Rahmoune H, Hong G, Gee A, Earnshaw D, Brown J (2003) The peripheral benzodiazepine receptor ligand PK11195 binds with high affinity to the acute phase reactant alpha1-acid glycoprotein: implications for the use of the ligand as a CNS inflammatory marker. Nucl Med Biol 30:199-206

33. Turkheimer FE, Rizzo G, Bloomfield PS, Howes O, ZanottiFregonara P, Bertoldo A, Veronese M (2015) The methodology of TSPO imaging with positron emission tomography. Biochem Soc Trans 43:586-592

34. Rizzo G, Veronese M, Tonietto M, Zanotti-Fregonara P, Turkheimer FE, Bertoldo A (2014) Kinetic modeling without accounting for the vascular component impairs the quantification of [(11)C]PBR28 brain PET data. J Cereb Blood Flow Metab Off J Int Soc Cereb Blood Flow Metab 34:1060-1069

35. Feeney C, Scott G, Raffel J, Roberts S, Coello C, Jolly A, Searle G, Goldstone AP, Brooks DJ, Nicholas RS, Trigg W, Gunn RN, Sharp DJ (2016) Kinetic analysis of the translocator protein positron emission tomography ligand [18F]GE-180 in the human brain. Eur J Nucl Med Mol Imaging 43:2201-2210

36. Tournier BB, Tsartsalis S, Ceyzériat K, Garibotto V, Millet P (2020) In Vivo TSPO Signal and Neuroinflammation in Alzheimer's Disease. Cells 9(9):1941

37. Fan J, Lindemann P, Feuilloley MGJ, Papadopoulos V (2012) Structural and functional evolution of the translocator protein (18 $\mathrm{kDa})$. Curr Mol Med 12:369-386

38. Todd MM, Weeks JB, Warner DS (1993) Microwave fixation for the determination of cerebral blood volume in rats. J Cereb Blood Flow Metab Off J Int Soc Cereb Blood Flow Metab 13:328-336

39. Schlepckow $\mathrm{K}$ et al (2020) Enhancing protective microglial activities with a dual function TREM2 antibody to the stalk region. EMBO Mol Med 12:e11227

Publisher's Note Springer Nature remains neutral with regard to jurisdictional claims in published maps and institutional affiliations. 